\title{
The gastropod Phorcus sauciatus (Koch, 1845) along the north-west Iberian Peninsula: filling historical gaps
}

\author{
Marcos Rubal · Puri Veiga $\cdot$ Juan Moreira • \\ Isabel Sousa-Pinto
}

Received: 5 September 2013/Revised: 13 December 2013/ Accepted: 8 January 2014/Published online: 21 January 2014

(c) Springer-Verlag Berlin Heidelberg and AWI 2014

\begin{abstract}
The intertidal gastropod Phorcus sauciatus is a subtropical grazer that reaches its northern boundary in the Iberian Peninsula. Distribution of $P$. sauciatus along the Iberian Peninsula shows, however, gaps in its distribution. The present study was aimed at detecting possible recent changes on the population structure and distribution of $P$. sauciatus along the north-west Atlantic coast of the Iberian Peninsula. To achieve this aim, we adopted a qualitative sampling design to explore the presence of $P$. sauciatus along a region within its historical gap of distribution (north Portuguese coast). In addition, a quantitative sampling design was adopted to test hypotheses about the abundance and size structure of $P$. sauciatus populations among regions with different historical records of its abundance and among shores with different exposure. Results showed that P. sauciatus was present along the north Portuguese coast. However, the abundance and size
\end{abstract}

Communicated by H.-D. Franke.

M. Rubal · P. Veiga · I. Sousa-Pinto

Laboratory of Coastal Biodiversity, Interdisciplinary Centre of

Marine and Environmental Research (CIIMAR/CIMAR),

University of Porto, Rua dos Bragas 289, 4050-123 Porto,

Portugal

M. Rubal ( $\square)$

Department of Biology, Faculty of Sciences, University of Porto, Via Panoramica 36, 4150-181 Porto, Portugal

e-mail: mrubal@ciimar.up.pt

P. Veiga $\cdot$ I. Sousa-Pinto

Department of Biology, Faculty of Sciences, University of Porto, Rua do Campo Alegre s/n, 4150-181 Porto, Portugal

J. Moreira

Departamento de Biología (Zoología), Universidad Autónoma de Madrid, Cantoblanco, 28049 Madrid, Spain structure of the newly settled populations were significantly different to those of the historically recorded populations. Moreover, P. sauciatus was able to establish populations at sheltered shores. Considering these results, we propose models for the distribution of $P$. sauciatus along the Iberian Peninsula, based on effects of sea surface temperature, and to explain the size-frequency of their populations based on their density.

Keywords Phorcus sauciatus - Iberian Peninsula . Distribution gaps · Rías · Distribution shifts

\section{Introduction}

The intertidal gastropod Phorcus (Osilinus) sauciatus (Koch 1841) is a common grazer along the rocky shores of subtropical east Atlantic and Macaronesia (i.e. Canary and Madeira islands, Dautzenberg 1910; Ramírez et al. 2005). The taxonomy of this species is complicated especially because of the many synonyms found across the literature (Donald et al. 2012). The northern boundary of its distribution is found at the warm-water Lusitanian area (i.e. north coast of the Iberian Peninsula and south Atlantic French coast) (Fischer-Piétte 1963). The first records of $P$. sauciatus (as Monodonta sagittifera) at the Iberian Peninsula were those by Hidalgo (1917) at different sites along the Atlantic coast. Later, Nobre (1940) found P. sauciatus on the south coast of Portugal (as Trochocochlea colubrina), but he did not find this species at the northernmost Portuguese localities referred by Hidalgo (1917). The inconsistence between the observations by these authors led Fischer-Piétte (1958) to propose that the distribution of $P$. sauciatus along the Iberian Peninsula had changed during the first half of the twentieth century. 


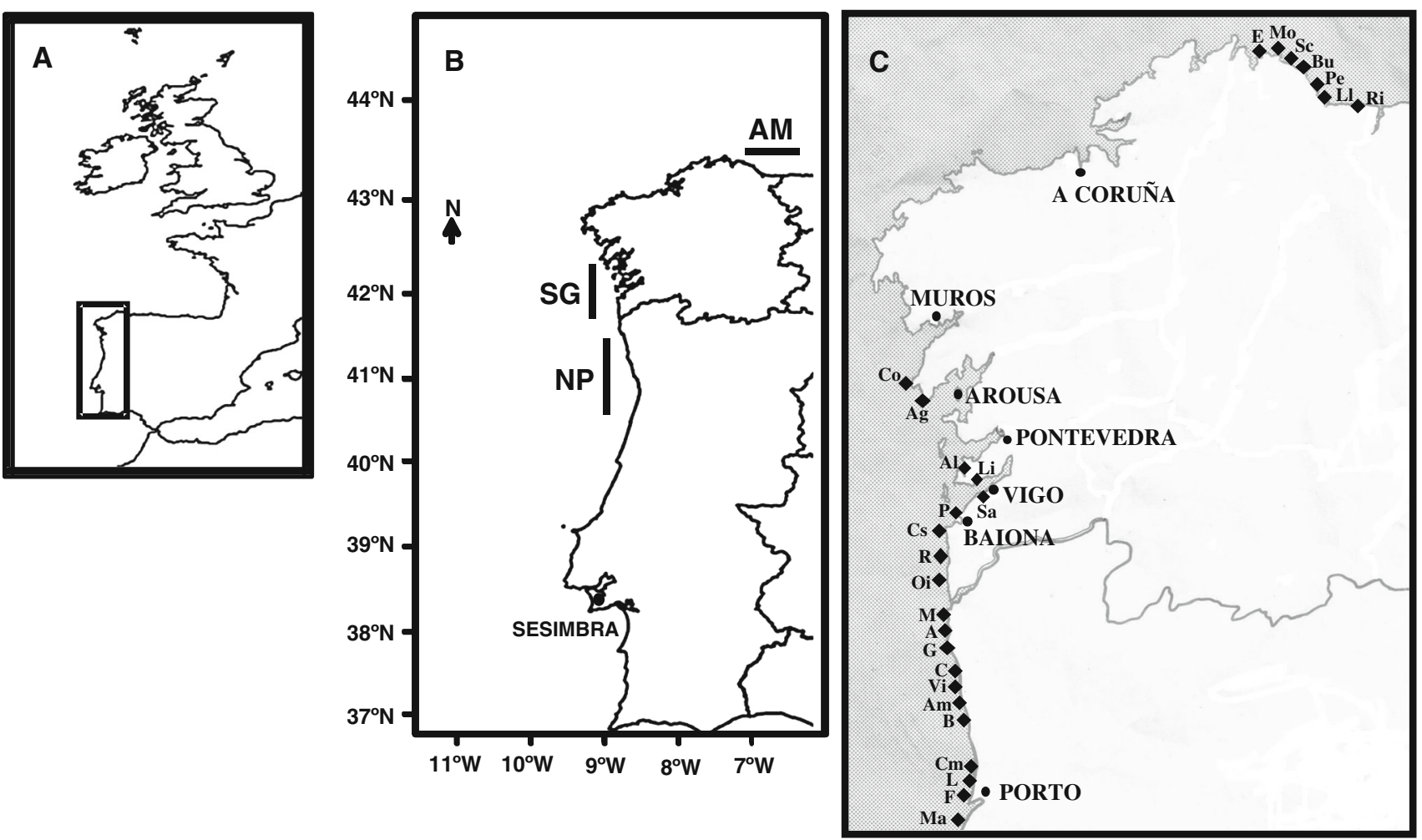

Fig. 1 a Atlantic coast of the Iberian Peninsula. b Location of the studied regions along the north-west Iberian Peninsula. c Location of the studied shores. Codes as in Table 1

Studies of the distribution of $P$. sauciatus along the Iberian Peninsula by the previous author reported the presence of P. sauciatus (as Monodonta colubrina) on the Atlantic Basque coast of France and along the north coast of the Iberian Peninsula (Fischer-Piétte and Kisch 1957; FischerPiétte 1963). However, the abundance of this species declined from A Coruña to Muros (Galicia, NW Iberian Peninsula; Fig. 1) and disappeared south from Muros to Sesimbra (central coast of Portugal; Fig. 1) with the exception of one individual found at Baiona (southern Galicia) (Fischer-Piétte and Kisch 1957; Fischer-Piétte 1963).

After these studies by Fischer-Piétte, most of the records and data about $P$. sauciatus in the Iberian Peninsula came from the Galician coasts. In 1975, an extensive survey along the Galician coast by Ansemil et al. (1977) found a similar distribution pattern as that described by FischerPiétte (1963). Later studies done by the end of the 1980s recorded the presence of $P$. sauciatus south of Muros, i.e. at the Ría de Arousa (Otero-Schmitt and Trigo-Trigo 1987) and the Ría de Pontevedra (Trigo-Trigo and Otero-Schmitt 1987) (Fig. 1).

Unfortunately, no record of the distribution of $P$. sauciatus on the Portuguese coast is available after the aforementioned studies by Fischer-Piétte. Boaventura et al. (2002) published an extensive survey about the main rocky intertidal organisms, but they did not discriminate between
P. sauciatus and Phorcus (Osilinus) lineatus (da Costa 1778). Similarly, recent data on the distribution of $P$. sauciatus in the north of the Iberian Peninsula are scarce; in fact, it has only been highlighted that this species has not been found in the intertidal of the Basque coast in the last 22 years (Borja 1987; Borja and Muxika 2001). Therefore, bibliographic information shows that the distribution of $P$. sauciatus along the Iberian Peninsula shows gaps on its distribution and they seem to be variable through time.

Fischer-Piétte (1963) related changes in distribution and abundance of intertidal organisms along the Iberian Peninsula with fluctuations in climate in general, and with those of surface seawater temperature (SST), in particular. Considering that $P$. sauciatus is a subtropical species, the distribution pattern found by Fischer-Piétte in the Iberian Peninsula could be explained by the upwelling regime. The actual presumed gaps on the distribution of $P$. sauciatus fit well with the area where the spring-summer upwelling is stronger and where sea water temperature decreases (Álvarez et al. 2011). The upwelling regime at the Iberian Peninsula has, however, decreased in frequency and intensity during the last decades (Lemos and Pires 2004; Gómez-Gesteira et al. 2008), and this upwelling relaxation has been related to recent changes on the distribution patterns of the subtropical limpet Patella rustica Linnaeus, 1758 on this area (Lima et al. 2006; Ribeiro et al. 2010). 
Moreover, the sea surface temperature (SST) has been increased at the north-east Atlantic due to global warming (Burrows et al. 2011; Lima and Wethey 2012). These changes in oceanographic conditions could result in shifts on the distribution and abundance of $P$. sauciatus along its northern boundary; such patterns have already been reported for other gastropods at this area (Lima et al. 2006) and other Phorcus species at northern latitudes (Mieszkowska et al. 2006, 2007).

Along the Atlantic coast of the Iberian Peninsula, $P$. sauciatus shares habitat with its co-generic $P$. lineatus and usually both can be found on the same shores (Ansemil et al. 1977). Many authors have proposed that $P$. sauciatus is more frequent at exposed habitats, while $P$. lineatus is more frequent at sheltered ones (Ardré et al. 1958; FischerPiétte and Seoane Camba 1962; Crothers 2001). Previous work has also reported the absence of $P$. sauciatus at the inner part of the Galician rías where P. lineatus is present instead (Ardré et al. 1958; Fischer-Piétte and Seoane Camba 1962; Ansemil et al. 1977). Significant environmental gradients are present along the rías, mainly related to salinity and exposure (Ardré et al. 1958). In the innermost areas of the rías, salinity is low and can fluctuate markedly; both $P$. sauciatus and P. lineatus do not occur there. Therefore, the lack of $P$. sauciatus in inner areas of the rías where salinity values are fully marine may be explained by the more sheltered conditions found there, when compared to outer, wave-exposed areas (Ansemil et al. 1977).

The overall aim of present study was to detect possible changes on the distribution pattern of $P$. sauciatus along the north-west Atlantic coast of the Iberian Peninsula. Therefore, differences in abundance and size structure of $P$. sauciatus populations from regions with different historical records of its abundance (i.e. absent, rare and abundant) and with different exposure conditions (i.e. outer and inner shores of rías) were tested. To achieve these aims, we adopted a qualitative sampling design to explore the presence of $P$. sauciatus along a region within its historical gap of distribution (north Portuguese coast). In addition, a quantitative sampling design was adopted to test hypotheses about the abundance and size structure of $P$. sauciatus populations among regions and among shores with different exposure.

\section{Materials and methods}

Study area

This study was carried out during August and September 2012 along the north-west Atlantic coast of the Iberian Peninsula (i.e. Galicia and north Portugal) (Fig. 1a). This area was selected due to the higher number of historical records of the presence and abundance of $P$. sauciatus in comparison with other areas. Three regions with different historical records of $P$. sauciatus were defined a priori (Fig. 1b): A Mariña (AM), where stable and abundant populations of $P$. sauciatus have been recorded since the last century (Fischer-Piétte and Kisch 1957; Fischer-Piétte and Seoane Camba 1962; Ansemil et al. 1977); South Galicia (SG), where P. sauciatus has occasionally been recorded during the last decades (Trigo-Trigo and OteroSchmitt 1987; Otero-Schmitt and Trigo-Trigo 1987) and North Portugal (NP), where P. sauciatus has never been recorded to date (Fischer-Piétte, 1963). Moreover, to explore the distribution of $P$. sauciatus at wave-exposed and sheltered shores, we selected different sites out and within the rías de Vigo and Aldán (Fig. 1c), where $P$. sauciatus has been previously recorded (Fischer-Piétte and Kisch 1957; Ardré et al. 1958; Ansemil et al. 1977).

Sampling design and collection of data

\section{Qualitative sampling}

An extensive survey was done at the main rocky shores along North Portugal to explore the presence of $P$. sauciatus in this region, where this species had not been previously reported (Fig. 1c). Rocky shores (Table 1) were visited at low tide and a group of 4 people searched for $P$. sauciatus individuals approximately for an hour.

\section{Quantitative sampling for comparisons among regions}

At each of the three aforementioned regions, seven rocky shores (Table 1) were selected (Fig. 1c). Each rocky shore was visited at low tide, and the abundance of $P$. sauciatus was quantified counting the number of individuals within 10 quadrats $(50 \times 50 \mathrm{~cm})$ that were randomly placed along the high shore because snails were usually present there. The maximum length of all individuals in any quadrat was measured with callipers to the nearest millimetre to quantify population size structure.

\section{Quantitative sampling for comparisons among shores with different exposure}

We selected two rocky shores at three different positions with respect to the inner part of the rías de Vigo and Aldán (Fig. 1c): two shores at the open coast (out of both rías), two shores at the outer part of both rías and two shores at the inner part of the Ría de Vigo showing salinity values similar to those in fully marine environments. The open shore sites are exposed to wave height from NW of about $3 \mathrm{~m}$, with maximum values of around $7 \mathrm{~m}$ from SW during 
Table 1 Location of the studied shores along the Iberian Peninsula. Quantitative sampling is indicated with "Q" and qualitative sampling with "q"

\begin{tabular}{|c|c|c|c|c|}
\hline Region & Shore & Sampling & Latitude & Longitude \\
\hline \multirow[t]{7}{*}{ A Mariña (AM) } & Rinlo (Ri) & Q & $43^{\circ} 33^{\prime} 38.76^{\prime \prime} \mathrm{N}$ & $7^{\circ} 6^{\prime} 36.80^{\prime \prime} \mathrm{W}$ \\
\hline & Llas (Ll) & Q & $43^{\circ} 34^{\prime} 50.86^{\prime \prime} \mathrm{N}$ & $7^{\circ} 15^{\prime} 56.70^{\prime \prime} \mathrm{W}$ \\
\hline & Peizas $(\mathrm{Pe})$ & Q & $43^{\circ} 35^{\prime} 20.02^{\prime \prime} \mathrm{N}$ & $7^{\circ} 16^{\prime} 48.22^{\prime \prime} \mathrm{W}$ \\
\hline & Burela (Bu) & Q & $43^{\circ} 40^{\prime} 37.55^{\prime \prime} \mathrm{N}$ & $7^{\circ} 22^{\prime} 49.33^{\prime \prime} \mathrm{W}$ \\
\hline & San Cibrao (Sc) & Q & $43^{\circ} 41^{\prime} 38.44^{\prime \prime} \mathrm{N}$ & $7^{\circ} 26^{\prime} 11.79^{\prime \prime} \mathrm{W}$ \\
\hline & Moras (Mo) & Q & $43^{\circ} 43^{\prime} 21.66^{\prime \prime} \mathrm{N}$ & $7^{\circ} 28^{\prime} 6.02^{\prime \prime} \mathrm{W}$ \\
\hline & Esteiro (E) & Q & $43^{\circ} 42^{\prime} 47.66^{\prime \prime} \mathrm{N}$ & $7^{\circ} 33^{\prime} 29.38^{\prime \prime} \mathrm{W}$ \\
\hline \multirow[t]{9}{*}{ South Galicia (SG) } & Corrubedo (Co) & Q & $42^{\circ} 34^{\prime} 39.68^{\prime \prime} \mathrm{N}$ & $9^{\circ} 5^{\prime} 25.33^{\prime \prime} \mathrm{W}$ \\
\hline & Aguiño (Ag) & Q & $42^{\circ} 31^{\prime} 5.65^{\prime \prime} \mathrm{N}$ & $9^{\circ} 0^{\prime} 42.07^{\prime \prime} \mathrm{W}$ \\
\hline & Aldan (Al) & Q & $42^{\circ} 17^{\prime} 54.52^{\prime \prime} \mathrm{N}$ & $8^{\circ} 50^{\prime} 52.43^{\prime \prime} \mathrm{W}$ \\
\hline & Limens (Li) & Q & $42^{\circ} 15^{\prime} 22.95^{\prime \prime} \mathrm{N}$ & $8^{\circ} 48^{\prime} 35.80^{\prime \prime} \mathrm{W}$ \\
\hline & Patos $(\mathrm{P})$ & Q & $42^{\circ} 9^{\prime} 12.77^{\prime \prime} \mathrm{N}$ & $8^{\circ} 50^{\prime} 2.58^{\prime \prime} \mathrm{W}$ \\
\hline & Samil (Sa) & Q & $42^{\circ} 12^{\prime} 3.95^{\prime \prime} \mathrm{N}$ & $8^{\circ} 47^{\prime} 6.94^{\prime \prime} \mathrm{W}$ \\
\hline & Cabo Silleiro (Cs) & Q & $42^{\circ} 6^{\prime} 37.50^{\prime \prime} \mathrm{N}$ & $8^{\circ} 54^{\prime} 0.87^{\prime \prime} \mathrm{W}$ \\
\hline & Roca Vista (R) & Q & $42^{\circ} 3^{\prime} 11.58^{\prime \prime} \mathrm{N}$ & $8^{\circ} 53^{\prime} 22.23^{\prime \prime} \mathrm{W}$ \\
\hline & Oia (Oi) & Q & $42^{\circ} 00^{\prime} 10.88^{\prime \prime} \mathrm{N}$ & $8^{\circ} 52^{\prime} 45.57^{\prime \prime} \mathrm{W}$ \\
\hline \multirow[t]{11}{*}{ North Portugal (NP) } & Moledo (M) & $\mathrm{Q} / \mathrm{q}$ & $41^{\circ} 50^{\prime} 29.53^{\prime \prime} \mathrm{N}$ & $8^{\circ} 52^{\prime} 28.67^{\prime \prime} \mathrm{W}$ \\
\hline & Âncora (A) & $\mathrm{Q} / \mathrm{q}$ & $41^{\circ} 49^{\prime} 27.49^{\prime \prime} \mathrm{N}$ & $8^{\circ} 52^{\prime} 28.51^{\prime \prime} \mathrm{W}$ \\
\hline & Gelfa (G) & $\mathrm{Q} / \mathrm{q}$ & $41^{\circ} 47^{\prime} 44.32^{\prime \prime} \mathrm{N}$ & $8^{\circ} 52^{\prime} 27.71^{\prime \prime} \mathrm{W}$ \\
\hline & Carreço (C) & $\mathrm{Q} / \mathrm{q}$ & $41^{\circ} 42^{\prime} 50.43^{\prime \prime} \mathrm{N}$ & $8^{\circ} 51^{\prime} 53.21^{\prime \prime} \mathrm{W}$ \\
\hline & Viana (Vi) & $\mathrm{Q} / \mathrm{q}$ & $41^{\circ} 41^{\prime} 49.79^{\prime \prime} \mathrm{N}$ & $8^{\circ} 51^{\prime} 10.52^{\prime \prime} \mathrm{W}$ \\
\hline & Amorosa (Am) & $\mathrm{q}$ & $41^{\circ} 38^{\prime} 34.97^{\prime \prime} \mathrm{N}$ & $8^{\circ} 49^{\prime} 29.17^{\prime \prime} \mathrm{W}$ \\
\hline & Belinho (B) & $\mathrm{Q} / \mathrm{q}$ & $41^{\circ} 34^{\prime} 10.16^{\prime \prime} \mathrm{N}$ & $8^{\circ} 47^{\prime} 52.48^{\prime \prime} \mathrm{W}$ \\
\hline & Cabo do Mundo (Cm) & $\mathrm{Q} / \mathrm{q}$ & $41^{\circ} 13^{\prime} 31.36^{\prime \prime} \mathrm{N}$ & $8^{\circ} 43^{\prime} 3.55^{\prime \prime} \mathrm{W}$ \\
\hline & Leça (L) & $\mathrm{q}$ & $41^{\circ} 12^{\prime} 15.98^{\prime \prime} \mathrm{N}$ & $8^{\circ} 42^{\prime} 57.36^{\prime \prime} \mathrm{W}$ \\
\hline & Foz $(\mathrm{F})$ & $\mathrm{q}$ & $41^{\circ} 09^{\prime} 15.55^{\prime \prime} \mathrm{N}$ & $8^{\circ} 40^{\prime} 50.46^{\prime \prime} \mathrm{W}$ \\
\hline & Madalena (Ma) & $\mathrm{q}$ & $41^{\circ} 07^{\prime} 19.95^{\prime \prime} \mathrm{N}$ & $8^{\circ} 40^{\prime} 5.32^{\prime \prime} \mathrm{W}$ \\
\hline
\end{tabular}

storms (Dias et al. 2002). In the outer part of the ría, swell is normally from NW and wave height decreased from $1.6 \mathrm{~m}$ in the outer part of the ria to $0.6 \mathrm{~m}$ in the inner part of the ría (Bernabeu et al. 2012). Each rocky shore was visited at low tide, and the abundance and size structure of $P$. sauciatus populations were quantified as previously described.

\section{Data analyses}

Analyses of variance (ANOVA) were used to test the hypothesis that the abundance of $P$. sauciatus will differ among the three considered regions with different historical records of its abundance. The analysis was based on a two-way model, including the factors Region (fixed, with three levels: AM, SG and NP) and Shore (random, nested in Region, with seven levels) with $n=10$. To test the hypothesis that the size structure of $P$. sauciatus populations will differ among the studied regions, the length-frequency of $P$. sauciatus at each area was individually compared with those of the other two regions by means of Kolmogorov-Smirnov tests (KS). The KS test is a nonparametric test that allows comparing two different one-dimensional continuous distributions considering differences both in the location and shape of two samples.

To test the hypothesis that the abundance of $P$. sauciatus will differ among the three considered types of shores according to position and exposure, abundance data were explored with analyses of variance. These were based on a two-way model, including the factors Exposure (fixed, with three levels: Open Shore, Outer part of the ría and Inner part of the ría) and Shore (random, nested in Exposure, with two levels) with $n=10$. To test the hypothesis that the size structure of $P$. sauciatus populations will differ among shores with different exposure, length-frequency of $P$. sauciatus at each type of shore was individually compared with those of the other two by means of KS tests. 

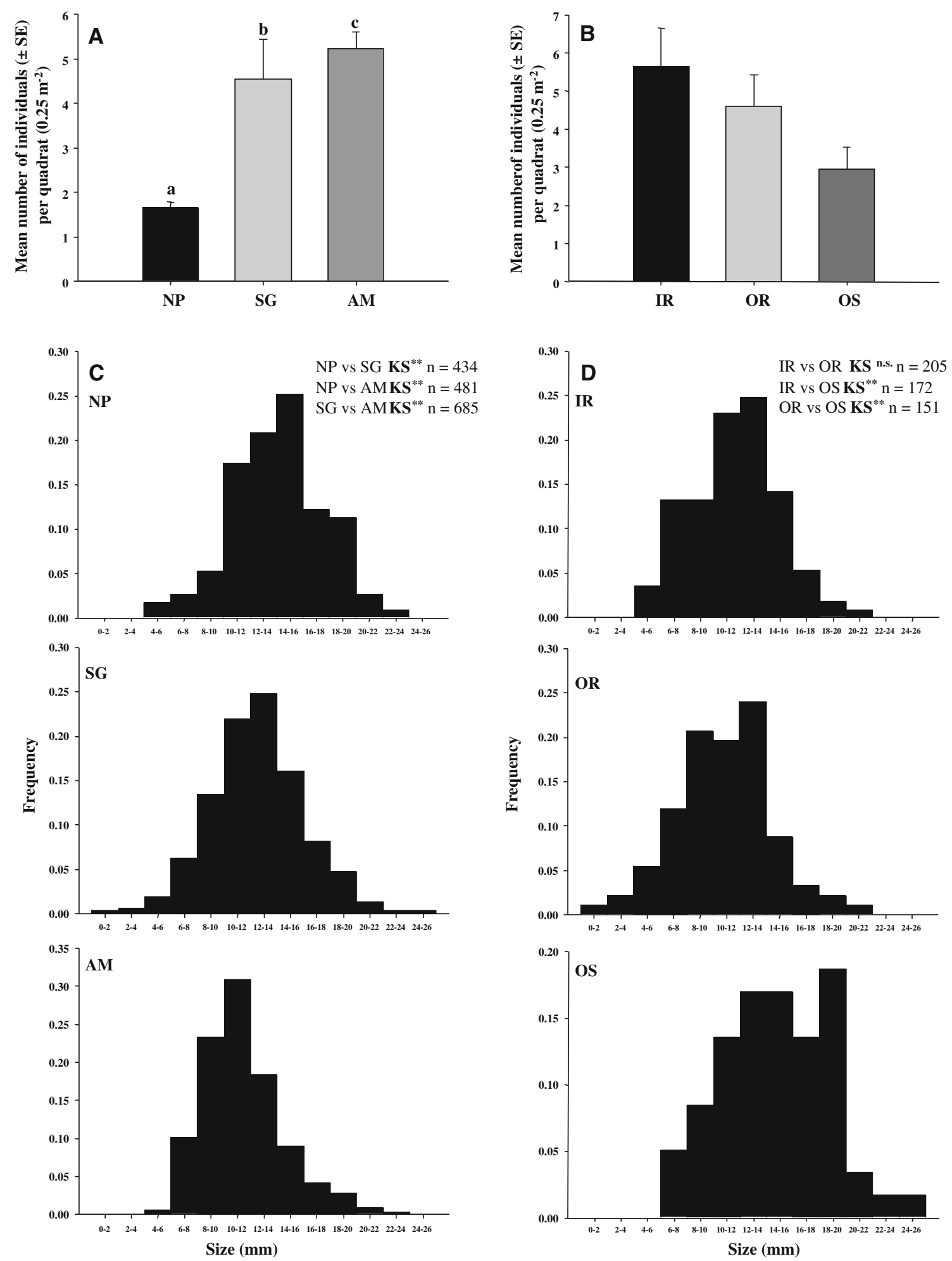

Fig. 2 a Mean abundance of $P$. sauciatus in the three studied regions North Portugal (NP), South Galicia (SG) and A Mariña (AM). Different letters indicate significant differences $(p<0.05)$ among regions. b Mean abundance of $P$. sauciatus according to exposure: Inner Ría (IR), Outer Ría (OR) and Open Shore (OS). c Size-

frequency of $P$. sauciatus populations in the studied regions. d Sizefrequency of $P$. sauciatus populations according to exposure. Results of KS test are showed. ${ }^{*}(p<0.05),{ }^{* *}(p<0.001)$, n.s. (not significant) 


\section{Results}

Qualitative sampling showed that in 2012, P. sauciatus was present at all sampled rocky shores in North Portugal, filling, at least partially, the historical gap described by Fischer-Piétte (1963). The abundance of $P$. sauciatus differed, however, among shores in North Portugal. We found just a few individuals at Amorosa (4 individuals), Leça (2), Foz (1) and Madalena (6). Therefore, these shores were not considered for the quantitative sampling.

Quantitative sampling showed a clear pattern in the abundance of $P$. sauciatus along the three regions studied (Fig. 2a) with the highest densities in A Mariña and the lowest densities in North Portugal. ANOVA (Table 2) showed that the abundance of $P$. sauciatus was significantly different among the three (Fig. 2a). Moreover, KS analyses showed that the size distribution frequencies of $P$. sauciatus were also significantly different among regions (Fig. 2b). In general, sizes from 6 to $12 \mathrm{~cm}$ were more frequent in A Mariña indicating recent recruitment while sizes of 14-24 cm were more frequent in North Portugal; sizes of 12-14 cm were more frequent in South Galicia.

ANOVA analysis made to explore the distribution of $P$. sauciatus at shores with different exposure (Table 3 ) did not show significant differences in abundance among the three studied types of shore (Fig. 2a). However, abundance showed a conspicuous trend consisting in higher densities at inner shores of the ría decreasing towards open shores. Finally, the KS analyses showed that size frequencies were significantly different among open shores and those placed at the outer and inner part of the rías (Fig. 2b). Sizes smaller than $14 \mathrm{~cm}$ were more frequent in Outer Ría and Inner Ría, while larger sizes (i.e. 14-26 cm) were more frequent in Open Shore. Outer Ría and Inner Ría did not show significant differences between their size frequencies (Fig. 2).

\section{Discussion}

The present study provided the first records of $P$. sauciatus in North Portugal, showing that this species has colonized, at least partially, its historical distribution gap as described by Fischer-Piétte (1963). Similar gap colonization was recently reported for $P$. rustica in North Portugal (Lima et al. 2006; Ribeiro et al. 2010). Moreover, results showed that historically recorded populations of $P$. sauciatus in A Mariña had similar densities and size-frequency structure than populations at its centre of distribution, i.e. Canary Islands (Ramírez et al. 2005). Therefore, we can consider A Mariña populations as reference for comparisons with the most recent populations found in South Galicia and North Portugal.
Population densities and size-frequency structure were significantly different among the three studied regions, supporting our first hypothesis. The observed decrease in number of individuals from A Mariña to North Portugal suggests that colonization occurred from the east and north in westward and southward direction. We found $P$. sauciatus populations at all studied shores in South Galicia with a mean density of 4.6 individuals per $0.25 \mathrm{~m}^{2}$, whereas early studies by Fischer-Piétte never recorded more than one individual of $P$. sauciatus at Baiona (Fischer-Piétte and Kisch 1957) and at the Ría de Vigo (Ardré et al. 1958). Ansemil et al. (1977) sampled 14 shores in South Galicia but only found four individuals of $P$. sauciatus among three shores within the Ría de Vigo. In the present study, we resampled four shores studied by Ansemil et al. (1977) where they had not found any individual of $P$. sauciatus (i.e. Co, $\mathrm{Ag}, \mathrm{Sa}$ and $\mathrm{Oi}$ ); we found, however, that nowadays these shores harbour important densities of $P$. sauciatus. Therefore, it seems that by the end of the $1970 \mathrm{~s}$, P. sauciatus was not present in South Galicia with the exception of sparse individuals at the Ría de Vigo, previously recorded by Fischer-Piétte and Kisch (1957) and Ardré et al. (1958). This scenario changed by the end of the 1980s with the record of $P$. sauciatus at the outer shores of the rías de Arousa and Pontevedra (Trigo-Trigo and Otero-Schmitt 1987; Otero-Schmitt and Trigo-Trigo 1987). These studies did not provide quantitative estimations of the density of $P$. sauciatus, but authors considered its abundance as rare or very rare. Therefore, by the end of the 1980s, the distribution of $P$. sauciatus had extended in South Galicia but populations were still reduced.

Considering the available bibliographic information, we can approximately date the beginning of the expansion in the distribution of $P$. sauciatus in South Galicia by the end of the 1980s and early 1990s. This expansion period coincides with a warming in the north-east Atlantic region, following the relatively cool period from late 1960s to early 1980s, that induced similar range expansion of warmwater species in the English Channel (Hawkins et al. 2003; Southward et al. 2005). Due to the lack of previous studies, it is more difficult to estimate the arrival of $P$. sauciatus to North Portugal. Considering the methods proposed by Williamson and Kendall (1981) to estimate the age of individuals of $P$. lineatus, the oldest specimen of $P$. sauciatus found in North Portugal in this study was about 8-9 years old and thus, we could date the arrival of this individual to the early years of this century. Considering that the expansion of $P$. sauciatus in South Galicia started at the end of the 1980s and early 1990s, it seems reasonable that this species had reached North Portugal during the first years of this century. This information should be considered with caution because the error estimating the age for old animals is higher than for young ones and animals older 
Table 2 Analysis of variance on the abundance of Phorcus sauciatus among the three studied regions

\begin{tabular}{lllllll}
\hline Source & SS & df & MS & $F$ & $p$ & $F$ versus \\
\hline Re & 47.1 & 2 & 23.5 & 13.8 & $<\mathbf{0 . 0 0 1}$ & Sh $(\operatorname{Re})$ \\
Sh $(\operatorname{Re})$ & 30.7 & 18 & 1.8 & 4.72 & $<\mathbf{0 . 0 0 1}$ & RES \\
RES & 68.3 & 189 & 0.36 & & & \\
TOT & 146.2 & 209 & & & & \\
Cochran's test & $C=0.1297$ (not significant) & Transform: $\operatorname{Ln}(X)$ \\
\hline
\end{tabular}

Bold values indicate significant differences

Table 3 Analysis of variance on the abundance of Phorcus sauciatus between sheltered and exposed shores

\begin{tabular}{lllllll}
\hline Source & SS & df & MS & $F$ & $p$ & $F$ versus \\
\hline Ex & 47.1 & 2 & 37.1 & 1.51 & $>0.05$ & Sh (Ex) \\
Sh $($ Ex) & 73.5 & 3 & 24.5 & 1.88 & $>0.05$ & RES \\
RES & 704.8 & 54 & 13.1 & & & \\
TOT & 852.4 & 59 & & & & \\
Cochran's test & C $=0.3611$ (not significant) & & \\
\hline
\end{tabular}

than 10 years were very uncommon at $P$. lineatus populations studied by Williamson and Kendall (1981). Therefore, individuals of $P$. sauciatus that had reached North Portugal previously to 2002 were probably not found during our sampling. It is remarkable that Mieszkowska et al. (2007) recorded a range extension of $P$. lineatus at the same time in Britain. In addition, Lima et al. (2006) found that $P$. rustica filled its historical gap in North Portugal around a similar date as we proposed for P. sauciatus. Moreover, they found that size-frequency distribution differed between historical populations and those found in North Portugal, the latter lacking small-sized individuals. We found a similar situation when comparing the sizefrequency of $P$. sauciatus among the three studied regions because large-sized individuals were more frequent in North Portugal and South Galicia than in A Mariña historically recorded populations. Lima et al. (2006) considered that the lack of small size classes may indicate that populations of $P$. rustica in North Portugal resulted from sporadic settlement events (Lewis 1986; Zacherl et al. 2003). We also found a lack of individuals of $P$. sauciatus for the sizes between 1 and $4 \mathrm{~mm}$ in North Portugal. However, we should consider that growth of Phorcus species is very fast after settlement; $P$. lineatus can reach $15 \mathrm{~mm}$ in size during their first year of life (Crothers 2001). When considering all size classes till $14 \mathrm{~mm}$, populations from North Portugal show lower frequencies than those from A Mariña but animals of these sizes were present, and probably included new recruits within sizes from 6 to $8 \mathrm{~mm}$. Shell shape and size of gastropods may be strongly influenced by abiotic (e.g. currents, exposure) and biotic factors (e.g. predation); however, the low frequencies of small size classes found in South Galicia and North Portugal could be related to a lower larvae supply or higher mortality during settlement, due to adverse environmental conditions at those regions. The importance of environmental conditions (especially temperature) on recruitment of the warm-water $P$. lineatus was observed by Crothers (1998). This author found that hot summer enhances the recruitment of $P$. lineatus and thus is reasonable to expect that low SST due to upwelling could reduce the recruitment of the subtropical P. sauciatus in South Galicia and North Portugal. This limited recruitment could explain the lower densities found in South Galicia and North Portugal. Moreover, the high frequency of large-sized classes in South Galicia and especially at North Portugal could be the result of low intra-specific competition due indeed to the low density found at these regions. The importance of the intra-specific competition on the size structure of the population of $P$. lineatus was proposed by Williamson and Kendall (1981). These authors found that high densities of $P$. lineatus resulted in slower growth rates but, after transplantation of specimens from high density populations to low density ones, their growth rate suffered a dramatic increase, despite the high abundance of other grazers and worse environmental conditions (Williamson and Kendall 1981).

During recent years, many studies reported an increase in the abundance and range of expansion for subtropical species such as $P$. rustica (Lima et al. 2006), Stramonita haemostoma (Linnaeus 1767) (Souto et al. 2008) and Siphonaria pectinata (Linnaeus 1758) (Rubal et al. 2013) at the Iberian Peninsula. These studies related the changes on the abundance and distribution of subtropical species directly or indirectly to climatic and oceanographic events that resulted in an increase in SST. Similar studies in the British islands have shown poleward range shifts of warmwater species in relation to SST increase (e.g. Hawkins et al. 2003; Southward et al. 2005; Mieszkowska et al. 2006, 2007). Temperature seems to play a major role shaping the range distribution of $P$. sauciatus. Low SST due to upwelling events seemed to be responsible for the absence of $P$. sauciatus in North Portugal and South Galicia. The summer cold-limitation hypothesis (Hutchins 1947) could be a plausible explanation for the historical gap in North Portugal and South Galicia. Similar results were proposed by Wethey and Woodin (2008) to explain the absence of the onuphid polychaete Diopatra neapolitana Delle Chiaje, 1841 in North Portugal. Basically, this theory proposes that low SST due to upwelling events during spring and summer prevents the recruitment of subtropical species (e.g. P. sauciatus) in North Portugal and South Galicia. However, the weakening of the upwelling since the 1940s has led to an increase in the SST 
on the coast about $+0.01{ }^{\circ} \mathrm{C}$ per year (Lemos and Pires 2004). This progressive increase in SST in South Galicia and North Portugal could be the responsible for the recent colonization of these regions by $P$. sauciatus but future manipulative experimental studies will be needed to test these models.

Secondly, we explored the abundance and population size structure of $P$. sauciatus at shores with different levels of exposure. Results showed that there were not significant differences in the abundance of $P$. sauciatus among shores with different exposure. Moreover, we found well-established populations of $P$. sauciatus on sheltered inner shores (i.e. Li and Sa) than those proposed by Ardré et al. (1958) as the limit of its distribution at the Ría de Vigo. Therefore, it seems that exposure is not a major constraint for $P$. sauciatus, because the range of distribution has extended colonizing sheltered shores where rocky substrate was available and salinity at fully marine values. However, size-frequency structure among the studied shores showed significant differences and, thus, supported partially the second hypothesis of this study. Populations from outer and inner parts of the ría did not show significant differences in size-frequency structure, and both the latter and their density values were similar to those from A Mariña. Therefore, it seems that sheltered conditions may be more favourable to $P$. sauciatus.

\section{Conclusions}

Recently, P. sauciatus has colonized its historical distributional gap in North Portugal, increasing its abundance and colonizing shores in South Galicia. This evolution on the distribution of $P$. sauciatus took place during the 1990s and the early years of the present century, probably related to changes on the SST due to the weakness of upwelling at these regions. However, the abundance and size structure of the newly found populations in South Galicia and North Portugal were significantly different to those of the historically recorded populations in A Mariña. Moreover, results showed that $P$. sauciatus was also able to establish populations at sheltered shores. The latter were very similar to those from exposed shores with the exception of slight differences in the size-frequency structure. Considering these results, we propose models to explain the distribution of $P$. sauciatus along the Iberian Peninsula, based on direct and indirect effects of SST, and to explain the size-frequency of their populations based on their density. These models should be experimentally tested in future studies.

Acknowledgments This study was partially supported by the European Regional Development Fund (ERDF) through the COMPETE-Operational Competitiveness Programme and national funds through FCT-Foundation for Science and Technology, under the project "PEst-C/MAR/LA0015/2011". During this study, M. Rubal (SFRH/BDP/81567/2011) and P. Veiga (SFRH/BPD/81582/2011) were supported by postdoctoral grants awarded by Fundação para a Ciência e Tecnologia (FCT, Portugal). The authors would like to thank Catarina Torres and Cristina Maldonado for their help in the sampling surveys. We are also grateful to two anonymous referees for all the helpful comments and suggestions, which have greatly improved this paper.

\section{References}

Álvarez I, Gómez-Gesteira M, deCastro M, Lorenzo MN, Crespo AJC, Dias JM (2011) Comparative analysis of upwelling influence between the western and northern coast of the Iberian Peninsula. Cont Shelf Res 31:388-399

Ansemil M, Rodríguez-Babio C, Urgorri V (1977) Estudio taxocenótico del género Monodonta Lamark en las costas Gallegas. Bol Soc Gal Hist Nat 1:77-104

Ardré F, Cabañas Ruesgas F, Fischer-Piétte E, Seoane J (1958) Petite contribution à une monographie bionomique de la Ria de Vigo. Bull Inst Océanogr Monaco 1127:1-56

Bernabeu AM, Lersundi-Kanpistegi A, Vilas F (2012) Gradation from oceanic to estuarine beaches in a ría environment: a case study in hte Ría de Vigo. Estuar Coast Shelf Sci 102-103:60-69

Boaventura D, Ré P, Cancela da Fonseca L, Hawkins SJ (2002) Intertidal rocky shore communities of the continental Portuguese coast: analysis of distribution patterns. Mar Ecol 23:69-90

Borja A (1987) Catálogo de los moluscos marinos de la costa vasca. Iberus 7:211-223

Borja A, Muxika I (2001) Actualización del catálogo de los moluscos marinos de la costa vasca, en las campañas realizadas por AZTI. Iberus 19:67-85

Burrows MT, Schoeman DS, Buckley LB, Moore P, Poloczanska ES, Brander KM, Brown C, Bruno JF, Duarte CM, Halpern BS, Holding J, Kappel CV, Kiessling W, O'Connor MI, Pandolfi JM, Parmesan C, Schwing FB, Sydeman WJ, Richardson AJ (2011) The pace of shifting climate in marine and terrestrial ecosystems. Science 334:652-655

Crothers JH (1998) A hot summer, cold winters, and the geographical limit of Trochocochlea lineata in Somerset. Hydrobiologia 378:133-141

Crothers JH (2001) Common topshells: an introduction to the biology of Osilinus lineatus with notes on other species in the genus. Field Stud 10:115-160

Dautzenberg P (1910) Faune malacologique de l'Afrique occidentale. Actes Soc Linn Bordeaux 44:1-174

Dias JMA, Gonzalez R, Garcia C, Diaz-del Rio V (2002) Sediment distribution patterns on the Galicia-Minho continental shelf. Prog Oceanogr 52:215-231

Donald KM, Preston J, Williams ST, Reid DG, Winter D, Alvarez R, Buge B, Hawkins SJ, Templado J, Spencer HG (2012) Phylogenetic relationships elucidate colonization patterns in the intertidal grazers Osilinus Philippi, 1847 and Phorcus Risso, 1826 (Gastropoda: Trochidae) in the northeastern Atlantic Ocean and Mediterranean Sea. Mol Phylogenet Evol 62:35-45

Fischer-Piétte E (1958) Sur l'écologie intercotidale Ouest-ibérique. C R Acad Sci (Paris) 246:1301-1303

Fischer-Piétte E (1963) La distribution des principaux organismes intercotidaux nord-ibériques en 1954-1955. Ann Inst Océanogr 150:165-311

Fischer-Piétte E, Kisch BS (1957) Sur la distribution de Monodonta colubrina Gould. Espèce nouvelle pour la faune française. J Conch 92:25-32 
Fischer-Piétte E, Seoane Camba J (1962) Ecologie de la ria-type: la Ría del Barqueiro. Bull Inst Océanogr Monaco 1244:1-36

Gómez-Gesteira M, de Castro M, Alvarez I, Gómez-Gesteira JL (2008) Coastal sea surface temperature warming trend along the continental part of the Atlantic Arc (1985-2005). J Geophys Res 113:C04010. doi:10.1029/2007JC004315

Hawkins SJ, Southward AJ, Genner MJ (2003) Detection of environmental change in a marine ecosystem-evidence from the western English Channel. Sci Total Environ 310:245-256

Hidalgo JG (1917) Fauna malacológica de España, Portugal y las Baleares. Moluscos testáceos marinos. Trab Mus Nac Cien Nat 30:1-752

Hutchins LW (1947) The bases for temperature zonation in geographical distribution. Ecol Monogr 17:325-335

Lemos RT, Pires HO (2004) The upwelling regime off the west Portuguese coast, 1941-2000. Int J Climatol 24:511-524

Lewis R (1986) Latitudinal trends in reproduction, recruitment and populations characteristics of some rocky littoral molluscs and cirripedes. Hydrobiologia 142:1-13

Lima FP, Wethey DS (2012) Three decades of high-resolution coastal sea surface temperatures reveal more than warming. Nat Commun 3:740

Lima FP, Queiroz N, Ribeiro PA, Hawkins SJ, Santos AM (2006) Recent changes in the distribution of a marine gastropod, Patella rustica Linnaeus, 1758, and their relationship to unusual climatic events. J Biogeogr 33:812-822

Mieszkowska N, Kendall MA, Hawkins SJ, Leaper R, Williamson P, Hardman-Mountford NJ, Southward AJ (2006) Changes in the range of some common rocky shore species in Britain: a response to climate change? Hydrobiologia 555:241-251

Mieszkowska N, Hawkins SJ, Burrows MT, Kendall MA (2007) Long-term changes in the geographic distribution and population structures of Osilinus lineatus (Gastropoda: Trochidae) in Britain and Ireland. J Mar Biol Assoc UK 87:537-545

Nobre A (1940) Moluscos marinhos e das águas salobras. Companhia editora do Minho, Barcelos

Otero-Schmitt JJ, Trigo-Trigo JE (1987) Adiciones a la fauna malacológica de la ría de Arousa (NO de España). Iberus 7:129-135
Ramírez R, Tuya F, Sánchez Jerez P, Fernández Gil C, Bergasa O, Haroun RJ, Hernández Brito JJ (2005) Estructura poblacional y distribución de los Moluscos Gasterópodos Osilinus atrata y Osilinus sauciatus en el intermareal rocoso de las Islas Canarias (Atlántico Centro-Oriental). Cienc Mar 31:697-706

Ribeiro PA, Branco M, Hawkins SJ, Santos AM (2010) Recent changes in the distribution of a marine gastropod, Patella rustica, across the Iberian Atlantic coast did not result in diminished genetic diversity or increased connectivity. J Biogeogr 37:1782-1796

Rubal M, Veiga P, Cacabelos E, Moreira J, Sousa-Pinto I (2013) Increasing sea surface temperature and range shifts of intertidal gastropods along the Iberian Peninsula. J Sea Res 77:1-10

Southward AJ, Langmead O, Hardman-Mountford NJ, Aiken J, Boalch GT, Dando PR, Genner MJ, Joint I, Kendall MA, Halliday NC, Harris RP, Leaper R, Mieszkowska N, Pingree RD, Richardson AJ, Sims DW, Smith T, Walne AW, Hawkins SJ (2005) Long-term oceanographic and ecological research in the Western English Channel. Adv Mar Biol 47:1-105

Souto J, Lustres-Pérez V, Fernández-Pulpeiro E (2008) Nuevos datos sobre la presencia del molusco gasterópodo Stramonita haemastoma (Linnaeus, 1766) en las costas gallegas. Nova Acta Cient Compostel (Biol) 17:97-104

Trigo-Trigo JE, Otero-Schmitt JJ (1987) Contribución al conocimiento de los moluscos marinos de la Ría de Pontevedra e isla de Ons. Iberus 7:121-128

Wethey DS, Woodin SA (2008) Ecological hindcasting of biogeographic responses to climate change in the European intertidal zone. Hydrobiologia 606:139-151

Williamson P, Kendall MA (1981) Population age structure and growth of the Trochid Monodonta lineata determined from shell rings. J Mar Biol Ass UK 61:1011-1026

Zacherl D, Gaines SD, Lonhart SI (2003) The limits to biogeographical distributions: insights from the northward range extension of the marine snail, Kelletia kelletii (Forbes, 1852). J Biogeogr 30:913-924 